\title{
Slavery and Abolition in Chartist Thought and Culture, I838-I850
}

\author{
Tom Scriven
}

School of History, Philosophy and Culture, Oxford Brookes University, Oxford, UK Email: tscriven@brookes.ac.uk

\begin{abstract}
In Britain between 1838 and 1858, the Chartist movement demanded the implementation of the 'Six Points', a parcel of parliamentary reforms centred on universal male suffrage. Despite the movement's recognized importance, little study has been made into Chartism's attitude towards slavery and abolitionism. This article will provide the first comprehensive study of this topic, from Chartism's origins in the 1830s until its decline in the decade after 1848. It will illustrate that Chartism was influenced by the radical labour component of the 'Democratic' coalition that supported President Andrew Jackson. This helped reinforce amongst early Chartists theories that wage labour was more exploitative than chattel slavery, alongside a racist reaction to West Indian emancipation more extreme than has previously been acknowledged. By 1842, however, various changes within the movement helped bring to the fore more consistently anti-slavery and even anti-racist sentiment with Chartist culture, as did growing exposure to American abolitionism, especially that of William Lloyd Garrison and Frederick Douglass. The development of the anti-slavery 'Free Soil' ideology amongst American labour radicals profoundly influenced the late Chartist position on slavery by inserting abolition into Chartist aspirations for land reform. Consequently, a core component of late Chartism was its own anti-slavery 'Free Soil' ideology, which greatly informed proUnion working-class agitation during the American Civil War.
\end{abstract}

On 4 July 1862, the editor of the Jersey Independent, George Julian Harney, sent Abraham Lincoln a copy of that day's editorial congratulating him for instigating 'the beginning of the end of American Slavery'. In an accompanying letter Harney elaborated on his own abolitionism:

A worker from youth in the cause of Political and Social Progression, I have naturally regarded American Slavery as the bane and shame of

(C) The Author(s), 2021. Published by Cambridge University Press. This is an Open Access article, distributed under the terms of the Creative Commons Attribution licence (http://creativecommons.org/licenses/by/4.0/), which permits unrestricted re-use, distribution and reproduction, provided the original article is properly cited. 
the American Union; and I rejoiced in your election as indicating the turning point in American history, and the resolution of the majority of the States to prevent the farther encroachment, of the Slave Power. Since the commencement of the Civil War I have marked your progress in the path which must finally lead to the emancipation of all the enslaved; and, in common with every friend of Freedom, I feel bound to express grateful acknowledgement of your courageous and consistent course. Persevere, Sir, in the same path, and you will command the sympathies and prayers of the friends of Free Institutions all over the World, and win for yourself the glorious reputation of the second "Father of the Republic"'.

On 23 October, surprised to have received a reply, Harney sent to Lincoln a copy of the Independent in which he praised the previous month's Preliminary Emancipation Proclamation. In his second letter, Harney explained that "I have always been an "abolitionist" - how could I be otherwise as a friend of democratic institutions and a believer in the principles of the "Declaration of Independence"?' He signed off by wishing Lincoln luck in 'the working out of the great mission which concerns not more the safety of the American Union, than the real and permanent welfare of all free nations and peoples struggling for Freedom.' ${ }^{1}$ Harney had been a prominent leader of Chartism, the mass-movement for the implementation of the 'People's Charter' for universal male suffrage, from the movement's initiation in 1838 until 1852. Between 1845 and 1850, he wielded considerable influence as the editor of its primary newspaper, the Northern Star. ${ }^{2}$ Although his correspondence with Lincoln has gone unnoticed, and his career as a Radical Republican after his migration to Boston in 1863 under-studied, his strong support for the Union, emancipation, and full equal rights for freedmen were continuations of a Chartist abolitionist ideology that he had helped craft. ${ }^{3}$

This ideology had, however, not been present at Chartism's birth in the years following the exclusion of most working men from the 1832 reform of parliament. ${ }^{4}$ The ensuing 1833 Emancipation Act that gradually abolished slavery in the British West Indies was vociferously attacked by working-class radicals for compensating slaveholders from a $£ 20,000,000$ fund, which as Patricia Hollis has outlined was seen as having been wrought from Britain's wage labouring 'white slaves', treated far worse than colonial chattel slaves. This

\footnotetext{
${ }^{1}$ George Julian Harney to Abraham Lincoln, 4 July, 23 Oct. 1862, Abraham Lincoln papers, Library of Congress (Lincoln's reply is lost); Jersey Independent, 4 July, 23 Oct. 1862. For context, see James M. McPherson, Battle cry of freedom: the American Civil War (London, 1990), pp. 455-89, 546-67.

${ }^{2}$ Malcolm Chase, Chartism: a new history (Manchester, 2007).

${ }^{3}$ Frank Gees Black and Renee Métivier Black, eds., The Harney papers (Assen, 1969); A. R. Shoyen, The Chartist challenge: a portrait of George Julian Harney (London, 1958), pp. 1-4; Owen Ashton and Joan Hugman, 'George Julian Harney, Boston, USA, and Newcastle upon Tyne, England, 1863-1888', Proceedings of the Massachusetts History Society, 107 (1995), pp. 165-84.

${ }^{4}$ For Chartism's emergence in the 1830s, see Dorothy Thompson, The Chartists: popular politics in the Industrial Revolution (London, 2013), pp. 9-62.
} 
opposition intensified once Chartism united disparate working-class radical groups into one movement pursuing reform, with Seymour Drescher attributing the decline of abolitionism in Britain as a popular movement as being in part due to Chartist hostility. ${ }^{5}$ As the first part of this article will outline, this discussion of 'white slavery' and its broader intellectual context has only been partial. While Hollis depicts it as a rejection of abolitionist individualism, the most prominent formulation of 'white slavery' sought to describe how the monopolization of land and capital in Britain had produced a dispossessed class of wage labourers, whose lack of access to any form of subsistence beyond their wages was supposedly worse than chattel slavery, wherein subsistence was believed to be guaranteed. Growing exchange with American labour radicals led to 'white slavery' developing as a transatlantic discourse. As a result, early Chartism was strongly influenced by the politics and culture of the 'Jacksonian Democracy', or the coalition of support behind American President Andrew Jackson, which opposed the growth of finance and industrial capital within America while including slaveholders within its white egalitarianism. This was incorporated by British radicals into a culture of racist resentment following West Indian emancipation, with attacks on 'white slavery' accompanied by apologias for slavery in the United States. ${ }^{6}$ A prominent characteristic of early Chartism was consequently a 'republican racism' similar to that identified by David R. Roediger amongst anti-slavery workers in America, based on the belief that slavery had degraded both the enslaved and free blacks beyond the capacity to act as citizens. ${ }^{7}$

The early 1840 s has been identified as a transitional period within Chartism, in which a new and broader leadership came to the fore more willing to question social relations than narrowly focus on political reforms. ${ }^{8}$ Chartism's intellectual culture was dominated by the movement's newspapers, which alongside political news printed satire, original essays, reports of Chartist lectures and demonstrations, and excerpts of political theory and scientific texts. The second part of this article will argue that the collapse of a number of those papers most hostile to West Indian freedmen and apologetic about American slavery will be shown to have had a lasting effect on the movement, as intellectuals came to the fore willing to revise understandings of the realities of

\footnotetext{
${ }^{5}$ Patricia Hollis, 'Anti-slavery and British working-class radicalism in the years of reform', in Christine Bolt and Seymour Drescher, eds., Anti-slavery, religion and reform: essays in memory of Roger Anstey (Folkestone, 1980), pp. 295-315; Seymour Drescher, Abolition: a history of slavery and antislavery (Cambridge, 2009), pp. 277-8; Richard Huzzey, Freedom burning: anti-slavery and empire in Victorian Britain (London, 2012), pp. 89-91.

${ }^{6}$ David R. Roediger, The wages of whiteness: race and the making of the American working class (London, 2007); Sean Wilentz, Chants democratic: New York City and the rise of the American workingclass, 1788-1850 (Oxford, 2005). See special issue of Journal of the Early Republic, 39, 1 (2019), esp. Joshua A. Lyyn and Harry L. Watson, 'Introduction: race, politics and culture in the age of Jacksonian "Democracy", pp. 81-7.

${ }^{7}$ Roediger, Wages, pp. 34-6.

${ }^{8}$ Chase, Chartism, pp. 192-270; Gregory Claeys, Citizens and saints: politics and anti-politics in early British socialism (Cambridge, 1989), pp. 223-60; Tom Scriven, Popular virtue: continuity and change in radical moral politics (Manchester, 2017).
} 
chattel slavery, the impacts of West Indian emancipation, and black political agency. ${ }^{9}$ The final two parts will outline how over the mid-1840s Chartism came to develop its own anti-slavery politics by combining a number of American sources. This included a growing embrace of the abolitionists around William Lloyd Garrison, who in distinction to most British abolitionists were perceived as republicans sympathetic to the grievances of British wage labourers. This will be shown to have been far wider within Chartism than has previously been thought, informing not only a growing moral criticism of slavery but also a reanalysis of 'white slavery' in response to abolitionist criticisms. Although Chartists did not see wage labour in Garrisonian terms as 'free', they did attempt to depict it as a form of slavery with benefits over chattel slavery. ${ }^{10}$ This occurred alongside a renewed exchange with the American labour movement, shown by Mark Lause and Jonathan Earle to have been developing in this period a Jacksonian strand of anti-slavery. ${ }^{11}$ This 'Free Soil' ideology sought to end 'white slavery' through homestead legislation that would relocate urban workers onto smallholdings in the western territories, a programme that necessarily drew them into conflict with monopolistic slaveholders. In Britain, Chartists were similarly pursuing with their 'Land Plan' the resettlement of urban workers onto Chartist estates as smallholders, and this article will outline how they increasingly adapted 'Free Soil' ideology to this British context. ${ }^{12}$ The result of these dual influences was a workingclass anti-slavery ideology that has not been previously described in British historiography: while vocalizing moral opposition to slavery, it also advocated abolition and black suffrage as part of a global emancipation of labour through the elimination of land monopoly. In this form, anti-slavery sentiment increased within Chartism during the period when Britain's abolitionist societies struggled to find mass support, despite widespread anti-slavery sentiment. ${ }^{13}$ This British 'Free Soil' tradition remained a component of Chartism until its final dissolution in 1858, and a legacy of this was significant ex-Chartist support for the Union and emancipation during the American Civil War, when well-rehearsed arguments for abolition were deployed to mobilize workers for the Union and emancipation. The success to these ends was, in part, because the ideology of the Republican Party was not only

\footnotetext{
${ }^{9}$ Joan Allen and Owen Ashton, eds., Papers for the people: a study of the Chartist press (Monmouth, 2005); Chase, Chartism, pp. 241-3.

${ }^{10}$ Betty Fladeland, "'Our cause being one and the same": abolitionists and Chartism', in James Walvin, ed., Slavery and British society, 1776-1846 (Baton Rouge, LA, 1982), pp. 69-99; W. Caleb McDaniel, The problem of democracy in the age of slavery: Garrisonian abolitionists and transatlantic reform (Baton Rouge, LA, 2013); Richard Bradbury, 'Frederick Douglass and the Chartists', in Alan J. Rice and Martin Crawford, eds., Liberating sojourn: Frederick Douglass and transatlantic reform (Athens, GA, 1999), 169-86.

${ }^{11}$ Jamie L. Bronstein, Land reform and working-class experience in Britain and the United States, 18001862 (Stanford, CA, 1999); Mark A. Lause, Young America: land, labor, and the Republican community (Chicago, IL, 2005); Jonathan H. Earle, Jacksonian antislavery and the politics of Free Soil, 1824-1854 (London, 2004).

${ }^{12}$ Chase, Chartism, pp. 247-70.

${ }^{13}$ Huzzey, Freedom burning, p. 13.
} 
compatible with but shared a considerable and recent heritage with British working-class radicalism. ${ }^{14}$ This, ultimately, raises questions about how we periodize Chartism, and understand both its aims and its longer influence.

In June 1833, the Whig government finalized their Emancipation Bill. Slaves in Britain's West Indian colonies would be emancipated after a twelve-year period of unpaid 'apprenticeship' to their masters, who would also receive $£ 20,000,000$ compensation. ${ }^{15}$ The bill came under criticism from Britain's working-class radicals, reorganizing after their agitation had failed to achieve universal suffrage in the 1832 Reform Act. For Bronterre O'Brien, editor of the influential Poor Man's Guardian, the 'poor negro' should be congratulated for securing a shorter working day for 'the same substantial comforts' but emancipation should not be at the expense of 'those who are greater slaves than themselves', meaning compensation would be unjust even if paid directly to the slaves. In O'Brien's understanding, this 'white slavery' occurred because a ruling class of aristocrats and capitalists had usurped Britain's land, forcing workers to rely upon wages as the only form of subsistence, therefore giving factory owners the coercive tool of the threat of starvation. In contrast, chattel slaves' subsistence was guaranteed, since as embodied capital their life and health were paramount to slaveholders. Only universal suffrage would provide workers with the means to pass the legislation redistributing the land and converting private industry into co-operatives. The description of British wage labourers as 'white slaves' differed from the purely political definition of slavery favoured by authors such as William Cobbett, and the specific notion that 'white slavery' was more coercive than chattel slavery because adult wage labourers lacked subsistence beyond the wage was chiefly O'Brien's formulation. Due to the Poor Man's Guardian's circulation of 15,000 and vastly higher readership, O'Brien was an important propagator of the idea that inequality was caused by property relations, and not just political disenfranchisement as emphasized by older thinkers like Cobbett, who died in 1835. By the first years of Chartism, O'Brien was widely considered the movement's 'schoolmaster' and by critics the purveyor of widespread 'mischievous doctrines regarding property'. ${ }^{16}$

O'Brien's development of 'white slavery' drew heavily after 1833 from the press of the American labour movement, and in particular George Henry Evans's New York Working Man's Advocate, which itself republished from the

\footnotetext{
${ }^{14}$ On this ideology, see Eric Foner, Free Soil, free labor, free men: the ideology of the Republican Party before the Civil War (Oxford, 1995). For its complex relationship with the 'Free Soil' of labour radicalism, see Earle, Jacksonian antislavery, pp. 13-16; and Lause, Young America, pp. 1-5, 112-37.

${ }^{15}$ Huzzey, Freedom burning, pp. 9-10; Poor Man's Guardian, 8, 15 June 1833. The period of apprenticeship was later reduced to four to six years.

${ }^{16}$ Ben Maw, 'Bronterre O'Brien's class analysis: the formative phase, 1832-1836', History of Political Thought, 28 (2007), pp. 253-89; William Cobbett, Eleven lectures on the French and Belgian Revolutions... (London, 1833), pp. 6-7; Poor Man's Guardian 15, 22 June 1833; The Destructive, 4 Jan. 1834; Northern Star, 30 Nov. 1839, 18 Sept., 2, 9 Oct., 27 Nov. 1841, 9 Apr. 1842.
} 
Poor Man's Guardian. ${ }^{17}$ Through this, O'Brien became a vocal supporter of the American President Andrew Jackson and his 'Democratic' coalition, which included southern slaveholders and northern workers. In early 1832, Jackson refused to renew the charter of the Bank of the United States, the US national bank, arguing that it siphoned the wealth of western farmers and artisans towards a transatlantic financial aristocracy, initiating the 'Bank War' with the Bank's supporters after his December re-election. For O'Brien, the Bank granted its shareholders a growing monopoly over the circulation of money, which consequently fuelled the monopolization of land, creating in America 'slavery, and all the miseries of life' like in Britain. Although only the conversion of private property into co-operatives would ultimately end this 'slavery', O'Brien saw the Bank's destruction as being beneficial for American and British workers, and Jackson's policies as illustrative of the necessity of universal suffrage. ${ }^{18}$ Consequently, by the mid-1830s, British working-class radicals venerated Jackson and even celebrated the 1837 transatlantic financial crash, thought at the time to be caused by his policies, as the beginning of a deflationary crisis that would destroy the Anglo-American money aristocracy. ${ }^{19}$ Despite the anti-slavery viewpoints occasionally expressed in Evans's papers, financial capitalists and land speculation, rather than chattel slavery, were seen as the chief threat to American workers. British radicalism's response to the revival of American abolitionist agitation in the mid-1830s was consequently muted. ${ }^{20}$

O'Brien's definition of 'white slavery' formed the abstract structure of a virulent anti-slave sentiment after strikes in the West Indies and agitation in Britain ended the apprenticeship system in August 1838, and slaves were ostensibly freed into wage labour with stronger legal protections and shorter working days than in Britain. ${ }^{21}$ This occurred alongside the birth of Chartism after the dissemination of the 'People's Charter' in June, and the apex of protests against the punitive New Poor Law, which had been growing since the law's implementation in 1835. O'Brien cautioned Chartists to ignore the apprenticeship agitation, led by hypocritical exploiters of wage labourers who had supported the removal of the Old Poor Laws, the last barrier of subsistence against 'white slavery'. His idea that guaranteed subsistence meant that chattel slavery was a more humane form of exploitation than wage labour, which

\footnotetext{
${ }^{17}$ Working Man's Advocate, 2 Apr. 1831, 15 Mar. 1834; Poor Man's Guardian, 8 Dec. 1832, 5 July, 18 Oct., 1 Nov., 13, 20, 27 Dec. 1834, 28 Nov. 1835; The Destructive, 3 Aug. 1833.

${ }^{18}$ Poor Man's Guardian, 8 Dec. 1832; Paul Kahan, The Bank War: Andrew Jackson, Nicholas Biddle, and the fight for American finance (Yardley, PA, 2016).

${ }^{19}$ Jackson's policies only partly contributed to the crisis: Jessica M. Lepler, The many panics of 1837: people, politics, and the creation of a transatlantic financial crisis (Cambridge, 2013).

${ }^{20}$ Roediger, Wages, pp. 77-9. For a rare example of the reporting of this revival, see Poor Man's Guardian, 28 Nov. 1835.

${ }^{21}$ Drescher, Abolition, pp. 264-5; Bridget Brereton, 'Family strategies, gender and the shift to wage labor in the British Caribbean', in Pamela Scully and Diana Paton, eds., Gender and slave emancipation in the Atlantic world (Durham, NC, 2005), p. 153; Gad Heuman, 'Riots and resistance in the Caribbean at the moment of freedom', in Howard Temperely, ed., After slavery: emancipation and its discontents (London, 2000), pp. 135-49.
} 
coerced through the threat of starvation, was now widely accepted. Responding to reports of work stoppages in the West Indies after the end of apprenticeship, Chartist newspapers decried emancipated slaves as "light-hearted, well-fed, and laughing negro[es]' whose 'listless and unmanageable' conduct created 'misery'. A history of paternalistic indulgence by the slaveholders, who were 'not all devils', coupled with hasty emancipation was blamed. The Northern Star, already Chartism's chief paper, was by 1839 uncritically repeating colonial representations of 'the Negroes as incorrigibility lazy and insolent'. The chief dissentient voice during this period was The Charter, edited by William Lovett, which argued the stoppages were labour disputes based on clear grievances with the planter class. ${ }^{22}$ Simultaneously, the Jacksonian influence also led early Chartists to downplay American slavery, drawing from southern Democrat papers to argue British factory 'slavery' was far 'worse than' Texan or Virginian slavery. For the Northern Liberator, 'these republicans', meaning slaveholders, 'almost to a man know that a system of white slavery, infinitely more cruel than any black slavery that ever existed either in the States or in our own Colonies, is carried on under the style and title of "The Factory System"'. ${ }^{23}$ After Chartists routinely interrupted abolitionist meetings in 1838 and again in 1840 to plead the case of the 'white slaves', pro-slavery Democrats responded gleefully. ${ }^{24}$

This discourse of British 'slavery' has been depicted as explicable in the context of harsh penalties for breaking employment contracts, but this does not explain why early Chartists coupled 'white slavery' with racist caricature. ${ }^{25}$ While Ryan Hanley has detailed the ossified white supremacism of radical authors William Cobbett and Richard Carlile in the 1820s, there is little direct support for his conclusion that this influenced the anti-abolition sentiment of the late 1830s. More evident was a widespread sentiment that black people had been debased by slavery, with 'negro servility' and 'negro-like submission' common radical insults towards whites. As with similar examples amongst American artisans, such republican racism was compatible with anti-slavery sentiment, since slavery was the source of black people's 'degradation'. ${ }^{26}$ This became interspersed with a mockery of black bodies and supposed manners. John Cleave had lived in the United States before returning to Britain to become the most successful radical publisher of the 1830s, and prior to 1841

\footnotetext{
${ }^{22}$ Bronterre's National Reformer, 7 Jan., 25 Feb., 28 Mar. 1837; The Champion, 21 Apr. 1838, 23 Sept., 23 Dec. 1839; The Chartist, 23 Feb., 9 June 1839; London Dispatch, 1 July 1838; Poor Man's Guardian, 15 Nov. 1834; Northern Star, 23 Mar., 29 June 1839; The Charter, 26 May, 9 June 1839.

${ }^{23}$ Poor Man's Guardian, 12 Apr. 1834; London Dispatch, 12 Mar. 1837; The Champion, 13, 27 Oct. 1839; Northern Star, 5 Sept. 1840; Northern Liberator, 6 June, 2 Oct. 1840.

${ }^{24}$ Huzzey, Freedom burning, pp. 10-12; Foner, Free Soil, pp. xviii-xix; Mississippian, 12 Mar. 1841; Pennsylvania Enquirer, 18 Feb. 1841; Emancipator and Free American, 20 June 1839.

${ }^{25}$ Huzzey, Freedom burning, pp. 84-93; Robert J. Steinfeld, Coercion, contract and free labor in the nineteenth century (Cambridge, 2001), pp. 1-28.

${ }^{26}$ Ryan Hanley, 'Slavery and the birth of working-class racism in England, 1814-1833', Transactions of the Royal Historical Society, 26 (2016) pp. 103-23; Poor Man's Guardian, 18, 25 Feb., 14 Apr. 1832, 2 Feb., 7 Dec. 1833; Working Man's Friend, 20 Apr. 1833; The Cosmopolite, 17 Mar., 28 Apr. 1832; The Destructive, 2 Mar. 1833; Roediger, Wages, p. 60.
} 
Britain's main purveyor of visual satire. ${ }^{27}$ One of his notable innovations was appropriating the imagery of blackface minstrelsy, a British craze since the arrival of 'Jim Crow' in 1836 from America. In a series of woodcuts in his comic papers between 1837 and 1841 politicians were ridiculed by being depicted in blackface minstrel garb, and an image of Jim Crow leading the Lord Mayor's procession sold in the 'thousands' on Lord Mayor's day $1840 .^{28}$ This continued earlier visual depictions by Cleave and his illustrator C. J. Grant of West Indian slaves as licentious and pampered, unlike the 'white slaves' of Britain, an idea that Cleave had repeatedly expressed during debates on the Emancipation Act. ${ }^{29}$ This anti-slave mockery was simultaneous with Chartist newspapers castigating emancipated slaves for refusing wages 'that the white slaves of our cotton factory system...would jump at' and mocking 'the hardships of the lazy blacks', who work at 'good wages for six hours a day, for six days in the week, ${ }^{30}$ The connection was explicitly made by Punch's argument in 1841 that blackface was popular because having paid for emancipation Britons resented ex-slaves refusing to work. ${ }^{31}$

\section{III}

As severe as this anti-abolitionism and racism became, signs of a shifting Chartist political culture were evident from 1840 onwards, a period of significant changes within Chartism's leadership and intellectual output. The largely artisanal London Working Men's Association (LWMA) was influential as the original producer of the People's Charter and in 1839 outmanoeuvred more radical factions to dominate London Chartism. Its leadership included the most important radical publishers of the period, including Cleave, and their publications regularly supplied Jeffersonian-Painite apologias for American slavery, redolent of American republican defences of the institution: although the 'blackest remnant of kingly dominion' imposed by Britain slavery was 'entirely a question for the consideration of the citizens' of the slave states, yet one that would die out as the 'aristocratic' south was eclipsed by the dynamic north. Regardless, American slaves 'never were abused as in our West India Colonies..$^{32}$ The LWMA itself produced in 1837 an address to American workers, questioning in a rare rebuke in the wake of Democrat electoral defeats why

${ }^{27}$ Ian Haywood, The rise of Victorian caricature (London, 2020), pp. 155-90.

${ }^{28}$ Alexander Saxton, 'Blackface minstrelsy and Jacksonian ideology', American Quarterly, 27 (1975), pp. 3-28; Tom Scriven, 'The Jim Crow craze in London's press and streets, 1836-1839', Journal of Victorian Culture, 19 (2014), pp. 93-109; Northern Star, 14 Nov. 1840; Cleave's Penny Gazette, 14 Nov. 1840.

${ }^{29}$ Poor Man's Guardian, 16 Feb., 13 Apr., 10 Aug. 1833; Slave Emancipation; Or, John Bull Gulled out of Twenty Millions (The Political Drama, No. 10: 1833); Morning Post, 22 Dec. 1835.

${ }^{30}$ Northern Star, 23 Mar. 1839; The Chartist, 7 July 1839.

${ }^{31}$ Punch, 6 Nov. 1841.

${ }^{32}$ David Goodway, London Chartism, 1838-1848 (Cambridge, 1982), pp. 38-45; Cleave's London Satirist, and Gazette of Variety, 28 Oct. 1837; London Dispatch, 15 Jan., 12 Mar., 22 Oct. 1837, 4 Feb. 1838; Roediger, Wages, pp. 34-5; Alexander Saxton, The rise and fall of the white republic: class politics and mass culture in nineteenth-century America (London, 2003), pp. 150-2. 
they had not voted to remove either slavery or the monopolies of 'swindling bankers and grinding capitalists'. The next September, however, they sent another address celebrating improved Democrat electoral fortunes, arguing that 'despite' slavery America was the most 'prosperous and free' country on earth because universal suffrage had extirpated the people's vices. ${ }^{33}$ In 1840, the LWMA disbanded and its membership became far less influential over both London and national Chartism. In the same year, the formation of the National Charter Association (NCA), the world's first mass-member political party, allowed poorer workers from more multi-ethnic trades to assume the leadership of Chartism via processes of regular, formal election. One of the most popular of these was William Cuffay, the Chatham-born son of a West Indian slave and a white English woman, who was elected to prominent leadership positions, including in 1842 the NCA's National Executive, and subsequently became a well-known figure within the national movement. ${ }^{34}$ Cuffay followed Scottish-Indian Dr John Taylor as the second mixed-race Chartist leader, while there existed a black orator amongst the Wolverhampton Chartists in 1842. The popularity of Cuffay and Taylor is illustrated by an address of Glasgow's Irish Chartists that they would follow anyone with 'moral energy' no matter 'his country...creed or the colour of his skin'. ${ }^{35}$ This consequently exposed Chartists to what could be considered a black Chartism: Cuffay refused to abandon his surname, an Anglicization of the Akan name Kofi, and linked this heritage to a universal emancipatory understanding of Chartism, telling a meeting that 'as a descendant of a West India slave, it would become [me] to be the friend of all who were struggling for freedom, ${ }^{36}$

While the NCA democratized the movement and allowed Cuffay's rise to a highly visible role as a national Chartist organizer, the purveyance of republican defences of American slavery also declined amid a turbulent period for the Chartist press. The Northern Liberator's defences of 'republican' slaveholders ended with the collapse of the paper in 1840, amid the repression of Newcastle Chartism. John Cleave's influence also waned in the early 1840s. In 1841, the Republican and Chartist Journal he published for the Lancashire Chartist Dr Peter McDouall collapsed, taking with it some of the most explicit apologies for American slavery. ${ }^{37}$ In January 1843, Cleave ended his English Chartist Circular, which had also defended American slaveholders as virtuous paternalists who oversaw a system that, while regrettable, was far better than Britain's 'white slavery'. ${ }^{38}$ These shifts were important, as they left the Northern Star the sole noteworthy Chartist newspaper just as it was becoming dominated by

\footnotetext{
${ }^{33}$ London Dispatch, 22 Oct. 1837; Cleave's London Satirist and Gazette of Variety, 15 Sept. 1838.

${ }^{34}$ Chase, Chartism, pp. 303-11.

${ }^{35}$ Wolverhampton Chronicle, 10 Aug. 1842, with thanks to Simon Briercliffe; Northern Star, 16 Oct. 1841.

${ }^{36}$ Northern Star, 28 Mar. 1846, 11 May 1850; G. J. Holyoake, Sixty years of an agitator's life, II (London, 1893), p. 3.

${ }^{37}$ McDouall's Republican and Chartist Journal, 3, 10 July 1841.

${ }^{38}$ Chase, Chartism, pp. 241-3; English Chartist Circular, vol. 1, nos. 6, 22, 52, vol. 2, nos. 53, 86 102, 144.
} 
Chartists who adopted a more vocally pro-abolition viewpoint. An early sign of this was the response to the debates around the repeal of the sugar duties. Designed during emancipation to protect the recently freed wage labourers from competition with slave-produced sugar, debates within parliament over ending the duties prompted in September 1842 a lengthy essay in the Northern Star entitled 'The West Indian capitalists and free labour'. The 'increasing prosperity of the negro population', the article sarcastically noted, was a sign of 'distress' for the planters. After explaining how low labour supply and opportunities for subsistence farming meant emancipated slaves were able to resist long hours and exploitative contracts, the article condemned plans to coerce Africans to the Caribbean colonies as an attempt to drive down wages and increase rents, thereby reversing emancipation. This 'indirect slavery' was necessary since 'a direct form is no longer possible'. Since throughout the world labour suffered wherever 'capital gains the ascendency over labour', the capital accumulation and wage depression would harm British workers alongside West Indians and Africans. Universal suffrage was therefore required to protect labour 'in the Colonies or at Home'. ${ }^{39}$

Historians have noted how, in the 1840s, many in British society became disillusioned with the results of West Indian emancipation, seeing slavery as having been replaced by a lax labour system under which freed slaves had refused to work, destroying the West Indian economy. As we have seen, many Chartists shared this belief between 1839 and $1840 .{ }^{40}$ On the contrary, 'The West Indian capitalists and free labour' saw this ability of freedmen to secure shorter hours and sources of subsistence other than the wage as an indication that emancipation had succeeded. Likely written by T. M. Wheeler, a socialist schoolteacher and the paper's London correspondent since 1840, the essay was the first prominent attempt not only to depict emancipation as freedom, but also illustrate why emancipation abroad aided, rather than hindered, British workers. ${ }^{41}$ This was made possible by the detailed reports of the Select Committees on the West Indies and West Africa, which the essay quoted comprehensively, and was spurred by the dispute between free traders and abolitionists over the extension of free trade to the West Indies. ${ }^{42}$ In Britain, Chartists argued that free traders sought cheap bread to drive down wages, and the essay alleged that the 'foreign-trade mania' also sought to immiserate black workers in the West Indies, concluding that British workers possessed a natural ally in West Indian freedmen. ${ }^{43}$ Although Chartist discussion of chattel slavery would come to increasingly focus on its retention in America, and not its legacy in the

\footnotetext{
${ }^{39}$ Northern Star, 3 Sept. 1842.

${ }^{40}$ Thomas C. Holt, The problem of freedom: race, labor, and politics in Jamaica and Britain, 1832-1938 (Baltimore, MD, 1992), pp. 179-82; Catherine Hall, Civilising subjects: metropole and colony in the English imagination, 1830-1867 (Cambridge, 2007).

${ }^{41}$ William Stevens, A memoir of T. M. Wheeler... (London, 1862).

${ }^{42}$ Richard Huzzey, 'Free trade, free labour, and slave sugar in Victorian Britain', Historical Journal, 53 (2010), pp. 359-79; Simon Morgan, 'The Anti-Corn Law League, and British anti-slavery in transatlantic perspective, 1838-1846', Historical Journal, 52 (2009), pp. 87-107.

${ }^{43}$ Paul A. Pickering and Alex Tyrell, The people's bread: a history of the Anti-Corn Law League (London, 2000), pp. 139-57; Northern Star, 3 Sept. 1842.
} 
West Indies, the Northern Star did report West Indian labour disputes and exploitative colonial migration schemes that reflected poorly upon both planters and free traders. Chartists came to support the sugar duties despite the increased cost to the consumer, a shift from the common Chartist position in $1840 .{ }^{44}$ This defence of emancipation became conjoined to a belief that freed slaves' rapid self-education was a model for British workers, and by the late $1840 \mathrm{~s}$ the Northern Star and Wheeler's novel Sunshine and Shadow emphasized how the emergence of black-owned newspapers and co-operatives in Jamaica heralded 'the Black Republic of the New World'. ${ }^{45}$

While opposition to free trade encouraged Chartists to rethink British emancipation, Harney's growing influence over the Northern Star elicited a revision of American slavery. The son of a Deptford sailor, Harney was brought up amid the multi-ethnic seafaring proletariat of London's East End and was converted to anti-slavery upon seeing a banner while attending a Greenwich election as a child. ${ }^{46}$ An internationalist and prominent leader of Chartism's republicansocialist wing in 1839, he began working for the Northern Star in 1842 and assumed most editorial responsibilities after becoming sub-editor in $1843 . \mathrm{He}$ was formally made editor in October 1845, with the proprietor Feargus O'Connor initially giving him a free hand. Harney had been a protégé of O'Brien in the 1830 s and was strongly attached to his critique of wage labour as a form of 'slavery'. O'Brien, however, had lost his influence over the movement following a dispute with O'Connor in 1840 and subsequently moved to the Isle of Man, leaving the deeply anti-slavery Harney as the most influential socialist within the movement. ${ }^{47}$ Harney followed American abolitionism from at least 1835. He came to draw both from the followers of William Lloyd Garrison, who believed the constitution guaranteed slavery and so refused to partake in elections, and the rival Liberty Party, who operated as an anti-slavery electoral party. ${ }^{48}$ As Harney's influence grew, the Northern Star reprinted reports of atrocities from Garrison's Boston Liberator and other American abolitionist newspapers, and would commit to defend 'the rights of all men, without regard to colour, clime or creed' and espouse that democracy 'comprises all; the negro as well as the white man' ${ }^{49}$ American abolitionist poetry also became prevalent in the Northern Star's important poetry column, a shift from the ambivalent position on slavery identified by Kelly J. Mays in Chartist poems before 1842. The publication of Liberty Party member John Greenleaf Whittier's Ballads and other poems in London in 1844 was of lifelong significance to Harney, who

\footnotetext{
${ }^{44}$ Northern Star, 20 Feb. 1841, 4, 11 June 1842, 14 Oct. 1843, 25 May 1844, 13 Dec. 1845, 4 Sept. 1847, 12 Feb. 1848; Huzzey, Freedom burning, pp. 93-7.

${ }^{45}$ Northern Star, 26 Sept. 1846, 20 Feb. 1847, 29 Mar., 3 May 1851; Ian Haywood, ed., Chartist fiction (Aldershot, 1999), pp. 114-15.

${ }^{46}$ Shoyen, The Chartist challenge, pp. 1-4; Peter Fryer, Staying power: the history of black people in Britain (London, 2010), pp. 227-37; David Goodway, ed., The Chartists were right: selections from the Newcastle Weekly Chronicle, 1890-1897 (London, 2014), pp. 126-7.

${ }^{47}$ Mike Sanders, The poetry of Chartism: aesthetics, politics, history (Cambridge, 2009), pp. 74-5; Black and Black, eds., Harney papers, p. 63.

${ }^{48}$ McDaniel, Problem of democracy, pp. 8-28; Black and Black, eds., Harney papers, pp. 165, 226.

${ }^{49}$ Northern Star, 2 Mar., 27 Apr., 4 May 1844, 28 Feb. 1846, 13 Nov. 1847.
} 
subsequently dubbed him and other abolitionists, including Garrison, 'the only poets America has yet produced' destined to longevity. ${ }^{50}$ In Harney's words Garrison and Whittier were valuable for being the opponents of the "wrongdooers and oppressors' of 'white as well as black', an important difference from most British abolitionists who remained distrusted by Chartists. ${ }^{51}$ These poetry columns were politically and aesthetically important to the movement, and Harney's consideration of these poets as worthy of emulation by Chartist worker-poets is indicative of the growing centrality of abolitionism to Chartism's intellectual culture. ${ }^{52}$

\section{IV}

Harney and many other Chartists were likely first exposed to Garrison during his 1840 tour of Britain when he, along with some American followers, had met with protestations from Chartists at a Glasgow meeting about British 'white slavery'. Garrison rebutted these arguments while also being clear that he sympathized with British workers' complaints and even criticized the complicity of British abolitionists in what he called their 'oppression', while his colleague Henry Clarke Wright went so far as to agree that British workers endured a form of 'slavery'. In response, Chartists helped the Garrisonian faction take control of the Glasgow Emancipation Committee (GEC) in early 1841, and by 1842 the British Garrisonian Elizabeth Peace Nichol and George Thompson had both become openly pro-Chartist. ${ }^{53}$ The Garrisonian lecturer Charles Lenox Remond, a free black barber from Massachusetts, also participated in the GEC meetings and upon witnessing 'the banner of a Chartist procession' approach him on the street, 'I joined it, and identified myself with them. ${ }^{54}$ In 1845, the fugitive slave and Garrisonian orator Frederick Douglass arrived in Britain, followed shortly after by Garrison himself, to begin another tour that would find a far wider popular audience. Although sympathetic to Chartist demands, and indeed describing himself as 'a Chartist' in 1848, Douglass sought upper-class support and refrained from commenting on British politics. ${ }^{55}$ Alongside Garrison, he sought to avoid the

\footnotetext{
${ }^{50}$ Kelly J. Mays, 'Slaves in heaven, laborers in hell: Chartist poets' ambivalent identification with the (black) slave', Victorian Poetry, 39 (2001), pp. 137-63; Northern Star, 9 Mar. 1844, 26 Apr., 28 June, 5 July 1845, 3 Jan. 1846; John G. Whittier, Ballads, and other poems (London, 1844); The Beacon, 21 Dec. 1853; Newcastle Weekly Chronicle, 17 Sept. 1892, 30 Sept. 1893.

${ }^{51}$ Northern Star, 30 Mar. 1844, 3 Jan., 28 Feb. 1846.

52 Sanders, Poetry of Chartism, pp. 69-86.

${ }^{53}$ McDaniel, Problem of democracy, pp. 66-88; Manisha Sinha, The slave's cause: a history of abolition (New Haven, CT, 2016), pp. 349-51; Report of the speeches...at the great public meeting of the Glasgow Emancipation Society...on the 27th July 1840 (Glasgow, 1840), pp. 14-15; Liberator, 18 Dec. 1840; Anna Davis Hallowell, ed., James and Lucretia Mott: life and letters (Boston, MA, 1884), p. 173; Northern Star, 13 Feb., 24 Apr., 1 May 1841, 29 Jan. 1842; Morning Post, 4 Aug. 1842; Anna M. Stoddary, Elizabeth Pease Nichol (London, 1899), p. 141.

${ }^{54}$ North Star, 5 May 1848, 26 Apr. 1850.

${ }^{55} \mathrm{He}$ did comment on the famine in Ireland, however: Liberator, 27 Mar. 1846; John R. McKivigan et al., eds., The Frederick Douglass papers, series 3, vol. I (London, 2009), p. 129; Fionnghuala Sweeney, Frederick Douglass and the Atlantic world (Liverpool, 2007), pp. 73-6; North Star, 14 July 1848.
} 
mainstream Chartist movement, whom both believed followed 'the violent course of Feargus O'Connor'. They gravitated instead towards the "'moral suasion" Chartists", a small London-based faction including the consistent abolitionist William Lovett, who organized as the "National Association for Promoting the Political and Social Improvement of the People', focusing largely on education and moral instruction. ${ }^{56}$ Nevertheless, Chartism was far less divided than the depiction by Garrison and Douglass and historians of abolition, and both men received support throughout the movement. ${ }^{57}$

In August 1846, the Anti-Slavery League (ASL) was founded in London by Garrison and Douglass with Lovett, the British abolitionist George Thompson, the former Chartist Henry Vincent, and the pro-Chartist writers William and Mary Howitt. ${ }^{58}$ Rather than seeing the ASL as a rival organization or a factional body, mainstream Chartists responded positively. The Northern Star sent a correspondent who commended the League's inaugural meeting and the paper thereafter regularly reported on the ASL, Garrison, and Douglass. Harney was close friends with the Howitts and thought highly of their People's Journal, the closest the ASL came to a publication. He urged Chartists to read it, and references to the Journal in correspondence in the Northern Star, as well as descriptions of Chartist reading rooms, suggest that some did. Alongside William Howitt's 'excellent article' outlining the ASL's formation, the Northern Star also extolled Harriet Martineau's portrait of Garrison, describing it as 'expos[ing] a state of things in America of which we had no previous conception', and upon meeting him in Boston in 1863, Harney found this 'previous admiration strengthened' by a 'true hero'. ${ }^{59}$ The ASL was poorly organized and dwindled in 1847, although Lovett claimed to Garrison that it 'made the subject of slavery plain and familiar to the minds of the millions'. ${ }^{60}$ This success was in part because Chartists were receptive to Garrisonianism during a particularly non-sectarian year for Chartism. A broad Chartist audience likely attended Garrison's speech at the National Association's 'National Hall' in Holborn where he extolled democracy and discussed his labouring roots, despite his claiming the audience were only 'moral suasion' Chartists. Although Lovett, the Hall's manager, had banned O'Connor in 1844, the Hall remained regularly used by the NCA, and Lovett's speeches there with Henry Clarke Wright throughout 1846 were well reported by the

\footnotetext{
${ }^{56}$ William Lloyd Garrison to Richard Davis Webb, 5 Sept. 1846: https://ark.digitalcommonwealth.org/ark:/50959/cv43qw369, accessed 5 Jan. 2021; McKivigan et al., eds., The Frederick Douglass papers, p. 129; William Lloyd Garrison, The story of his life, III (New York, NY, 1889), p. 159.

${ }^{57}$ Fladeland, 'Abolitionists and Chartism', pp. 85-6, 97-8; McDaniel, Problem of democracy, pp. 150-1; Chase, Chartism, pp. 168-78, 193-201, 226-9; Scriven, Popular virtue, pp. 96, 103-24.

${ }^{58}$ Fladeland, 'Abolitionists and Chartism', p. 97; Chase, Chartism, p. 307.

${ }^{59}$ Daily News, 19 Aug. 1846; Northern Star, 25 July, 22 Aug., 19 Sept., 7, 14 Nov., 26 Dec. 1846, 23, 30 Jan., 10 Apr., 22 May, 18 Sept. 1847; People's Journal, II (London, 1847), pp. 136-7; Black and Black, eds., Harney papers, pp. 22-5, 87-8, 164-5, 246-7.

${ }^{60}$ Liberator, 26 Mar. 1847; Simon Morgan, 'The political as personal: transatlantic abolitionism, c. 1833-1867', in William Mulligan and Maurice Joseph Bric, eds., A global history of anti-slavery politics in the nineteenth century (London, 2013), pp. 78-96, at p. 83.
} 
Northern Star. Harney later stressed his good working relations with Lovett despite their factional differences. ${ }^{61}$

During the tour, Douglass developed a wide Chartist following. His lectures offered free or cheap entry to audiences he described as the 'democratic element in British politics', and several Chartists later recalled attending them. The presence of a Northern Star correspondent at his Wakefield speech suggests Chartist attendance was common in the movement's heartlands. ${ }^{62}$ At the end of his tour, the paper reported his farewell soiree and reprinted his letter on the discrimination he received while boarding the SS Cambria at Liverpool. Harney remained an admirer of Douglass into the 1860s, when he recalled this act of 'gross social oppression'. ${ }^{63}$ In December 1846, the Northern Star directed its readers towards the 'Memoir of Frederick Douglass' in the People's Journal, which closely followed his Narrative of Frederick Douglass published in Dublin earlier in the year. ${ }^{64}$ The following year, the Narrative was published in a far cheaper edition by Joseph Barker of Leeds, a prominent Chartist publisher, speaker, and election candidate. ${ }^{65} \mathrm{~A}$ long-term abolitionist, in 1846 Barker began a series of cheap political and moral tracts for workers with a $1 \mathrm{~s}$ compendium on American slavery that included the first British publication of the memoirs of the refugee slaves Lewis and Milton Clarke. ${ }^{66}$ After becoming friends with Garrison and Douglass, he produced his 'English Edition' of the Narrative, which at $6 \mathrm{~d}$ was affordable for British workers. ${ }^{67}$ While this version of the Narrative was sold by Chartist booksellers well into the 1850s, when it was reduced to $3 d$, Barker also sold the Liberator and Douglass's North Star, and in 1848 produced a halfpenny pamphlet of Douglass's speech on the anniversary of emancipation in the West Indies. ${ }^{68}$ Douglass's entry into the Chartist literary canon was important, since the Narrative directly countered misconceptions at the heart of the

${ }^{61}$ William Lloyd Garrison, American slavery: address on the subject of American slavery, and the progress of the cause of freedom throughout the world... (London, 1846); Northern Star, 3, 24 Sept., 15, 29 Oct. 1842, 25 Mar., 1 Apr. 1843, 20 Apr., 15 June, 31 Aug. 1844, 18 Jan. 1845, 7 Feb., 23 May, 1 Aug., 3, 19, 24 Sept. 1846; Daily News, 14 Aug. 1846.

${ }^{62}$ Robert Crowe, The reminiscences of Robert Crowe, the octogenarian [!] tailor (New York, NY, 1902 [?]) p. 27; Philip Foner, ed., Life and writings of Frederick Douglass, I (New York, NY, 1950), p. 165; Newcastle Weekly Chronicle, 20 Feb. 1892; Northern Star, 23 Jan. 1846; John Stauffer and Henry Louis Gates Jr, eds., The Portable Frederick Douglass (New York, NY, 2016), p. 130. For prices, see Bristol Mercury, 29 Aug. 1846; Glasgow Herald, 26 Oct. 1846; Leeds Mercury, 9 Jan. 1847; Bradford Observer, 14 Jan. 1847.

${ }^{63}$ Northern Star, 27 Mar., 3, 10 Apr., 10 July, 9 Oct. 1847, 23 Sept. 1848, 24 Feb., 26 Dec. 1849; North Star, 14 July 1848; Jersey Independent, 10 July 1860, 29 Nov. 1862.

${ }^{64}$ Northern Star, 26 Dec. 1846; People's Journal, III (London, 1847), pp. 302-5.

${ }^{65}$ Betty Fladeland, Abolitionists and working-class problems in the age of industrialization (Baton Rouge, LA, 1984), pp. 132-70; Northern Star, 30 Mar. 1844, 26 June 1847, 10, 17 June, 1, 8 July, 12 Aug., 16 Sept., 28 Oct. 1848, 9 Nov. 1850; Newcastle Weekly Chronicle, 19, 26 Dec. 1896; Robert Gammage, History of the Chartist movement (London, 1854), p. 347.

${ }^{66}$ Interesting memoirs and documents relating to American slavery... (London, 1846); Liberator, 9 Apr. 1847.

${ }^{67}$ Frederick Douglass, Narrative of the life of Frederick Douglass, an American slave (Wortley, 1846).

${ }^{68}$ The People, II (1851), p. 23; ibid., III (1851), p. 31; Frederick Douglass, First of August address at Canandaigua (Leeds, 1848). See adverts in Barker's Reformer's Almanac, Feb.-Mar. 1848, and his gift of 20,000 books for the Newcastle Chartists to sell in 1853: People's Paper, 4, 11, 18 June, 27 Aug. 1853. 
'white slavery' comparison. Documenting the realities of physical brutality, sexual exploitation, and familial separation, Douglass also explained how holidays and food allowances were forms of social control and torture, buttressing his elucidation of the relative freedoms of wage labour. ${ }^{69} \mathrm{~A}$ school in Altrincham aimed at 'democrat' parents listed Barker's Narrative as a core text, implying it was valued as an instructive text by Chartists years before the 'mania' for Uncle Tom's Cabin, and the future union leaders Thomas Burt and Robert Applegarth both found it transformative during their Chartist youths. ${ }^{70}$

Douglass criticized the popularity of minstrelsy and racist caricature in Britain and Ireland, combatting it by including in the Narrative an etched portrait of himself based on a daguerreotype. This appeared in Barker's cheap edition that circulated amongst Chartists. ${ }^{71}$ Along with Douglass's speeches and writings, this well-dressed, formal, and static image provided thousands of British workers with a dignified, intellectual depiction of black masculinity that confronted minstrelsy. ${ }^{72}$ Chartists depicted Cuffay similarly after his transportation, having been convicted for insurrectionary plotting inspired by the revolutionary wave of 1848. In an 1850 biography, Cuffay was described by his friend Wheeler as an intellectual 'scrupulously neat in his person', a characteristic represented in a sketch by Cuffay's Newgate cellmate, the Irish Chartist William Dowling, later published as a lithograph. ${ }^{73}$ Cuffay's multifaceted role within Chartism as an orator, organizer, and accountant was distinct from the patronizing and ridiculous depiction of black people common to minstrelsy, which he also directly challenged by singing democratic songs at Chartist soirees organized with his wife Mary-Ann. This was significant, as the Northern Star correspondent's excitement at witnessing a black man 'accompanied by two fiddlers, dancing Jim along Josey in real Nigger style' among the festivities at a grand Nottingham outdoor meeting in July 1842 suggests that like many Britons and Americans Chartists perceived minstrelsy as an accurate depiction of black culture and innate musical ability. ${ }^{74}$ The extent of the decline of such sentiment amongst Chartists is difficult to assess, since anti-slavery thought often did not preclude racist sentiment. Some, for instance, may have exoticized Cuffay's singing as examples of an innate racial talent. ${ }^{75}$ Nevertheless, Cuffay's status, which continued well after his transportation,

${ }^{69}$ Frederick Douglass, Narrative of the life of Frederick Douglass, an American slave (New York, NY, 2014), pp. 74-6, 80-1, 92, 104-7.

${ }^{70}$ Thomas Burt, The autobiography of Thomas Burt (London, 1924), p. 19; A. W. Humphrey, Robert Applegarth: trade unionist, educationist, reformer (Manchester, 1913), pp. 5-6; The People, III (1851), p. 423; Sarah Meer, Uncle Tom mania: slavery, minstrelsy, and transatlantic culture in the 1850s (Athens, OH, 2005).

${ }^{71}$ John Stauffer, Zoe Trodd, and Celeste-Marie Bernier, Picturing Frederick Douglass: an illustrated biography of the nineteenth century's most photographed American (London, 2018), pp. 68-70; North Star, 7 Apr. 1849; McKivigan et al., eds., The Douglass papers, p. 79.

${ }^{72}$ Stauffer, Trodd, and Bernier, Picturing Frederick Douglass, pp. xi-xxx.

${ }^{73}$ Reynolds's Political Instructor, 13 Apr. 1850; Northern Star, 11 May 1850.

${ }^{74}$ Northern Star, 30 July, 12 Nov. 1842, 11, 25 Nov. 1843, 3 Jan. 1844; Eric Lott, Love and theft: blackface minstrelsy and the American working class (Oxford, 2013).

${ }^{75}$ Audrey A. Fisch, "'Negrophilism” and British nationalism: the spectacle of the black American abolitionist', Victorian Review, 19 (1992), pp. 20-47. 
indicates that at least some Chartists had come to view themselves as part of a 'multi-ethnic proletariat', as Satnam Virdee contends. ${ }^{76}$ Douglass later observed that in governments without universal suffrage exclusion based on property, rather than race, would bring 'no special stigma' for black people, suggesting in such polities class could over-ride racial distinction as mingling 'with the mass...I should partake of the strength of the mass, I should be supported by the mass' ${ }^{77}$ As Wheeler decried, Cuffay received stigma as both a 'proletarian' and 'scion of Africa's oppressed race', but also noted, in a phrase similar to Douglass's formulation, that he was 'loved by his own order'. ${ }^{78}$ In this, he joined a late Chartist black pantheon, with Douglass and the Haitian revolutionary Toussaint L'Ouverture revered for decades. ${ }^{79}$

The popularity of these Garrisonian 'Disciples of Thomas Paine' made plain the reality of slavery and pro-slavery violence and established the case for the moral urgency of abolition. However, few Chartists accepted Garrisonianism's pacificism, its electoral non-participation, or its defence of wage labour as freedom. Chartists remained supporters of an American popular reform party in the Jacksonian model, evident in how the Northern Star marked Jackson's 1845 death ${ }^{80}$ Yet during this same period, Chartist intellectuals rethought how wage labour related to American slavery and came to reject the Democrats for their support for slavery. The fulcrum of this shift was the development of a social programme focused on land reform, developed hand in hand with American labour radicals. Unlike the Jacksonian 'Bank War', this necessarily required a confrontation with slaveholders as land monopolists.

For Garrison and Douglass, wage labour was free regardless of abuses since it was based on personal liberty, or 'self-ownership'. The renewed agitation of George Henry Evans instead provided Chartists with a means of merging abolition with critiques of wages as a form of 'slavery'. After retiring to a farm in the late 1830s, Evans resumed publishing the Working Man's Advocate in 1844, renaming it in 1845 Young America. Evans became a key supporter of the National Reform Association (NRA), founded by the ex-Chartist Thomas Devyr. These 'Agrarian Reformers' sought legislation to end the trade of western public land and use it to provide homesteads for the 'wages-slaves' of urban surplus labour, thereby increasing wages and dispersing land monopolies. Within this, Evans developed his ideology of 'Free Soil', or the defending

\footnotetext{
${ }^{76}$ Satnam Virdee, Racism, class, and the racialized outsider (Basingstoke, 2014), pp. 30-1. Efforts on Cuffay's behalf continued long after his transportation: Northern Star, 22, 29 Mar. 1851; Reynolds's Newspaper, 16 Feb. 1851, 17 May 1857.

${ }^{77}$ The equality of all men before the law claimed and defended... (Boston, MA, 1865), p. 37.

${ }^{78}$ Reynolds's Political Instructor, 13 Apr. 1850; Northern Star, 11 May 1850.

${ }^{79}$ G. J. Holyoake, Sixty years of an agitator's life, I (London, 1893), pp. 98-9; Black and Black, eds., Harney papers, p. 163; Crowe, Reminiscences, pp. 27-8; Newcastle Weekly Chronicle, 27 Jan. 1894, 28 Mar. 1896.
}

${ }^{80}$ Northern Star, 19, 26 July, 2 Aug. 1845, 14 Nov. 1846. 
of political rights and participation through widespread smallholding. ${ }^{81}$ By 1842 , land reform was also increasingly posited by Chartists as the solution to the unemployment and cost of living crisis lingering since $1837 .^{82}$ In 1840, Feargus O'Connor argued that primogeniture had produced large inefficient farms and the 'serfdom' of fixed rents on poor leases, adding in an 1843 book co-written with Wheeler that this had been exacerbated by enclosure. This alienation from the land produced 'slave-labour...an artificial surplus population in the labour market' allowing the low wages that produced profit for capitalists. O'Connor and Wheeler proposed as the solution the Chartist 'Land Plan', a scheme in which individuals would pay a subscription into a central fund, from which land would be purchased and estates built, centred on a Chartist 'schoolhouse' where the settlement would be democratically run. The subscribers would then be resettled onto familial smallholdings on these estates from where they would farm for both subsistence and profit, thereby increasing wages generally. To these ends, the Chartist Land Co-operative Society was founded in 1845 , attracting widespread support, although it only established a handful of settlements before its 1850 collapse. ${ }^{83}$ Both projects shared intellectual roots in the Anglo-American agrarian tradition, but Evans was also directly influenced by O'Connor and O'Brien and considered Chartism the 'Free Soil movement of England'. ${ }^{84}$ He was also impressed by Harney and the Northern Star's detailed knowledge of the NRA. The Northern Star, O'Connor, and O'Brien all now developed an American following. ${ }^{85}$

This was facilitated by 'Agrarian' visitors to Britain alongside the vast Chartist exile population in America, many of whom initially joined the Democrats. However, by 1844, the Northern Star reported many émigrés 'astonished and disgusted by realities so painfully different to their own imaginings'. Although still praising the Democrats' 'anti-bank and anti-factory principles', the paper described the New York party as corrupt, and for the first time criticized the Democrats as 'supporters of slavery' who voided principle for southern votes. Whereas in the 1830s British radicals had focused on transatlantic finance capitalists alone as their opponents, the shift to land reform required an attack on slaveholders' land monopolies. ${ }^{86}$ At first glance, the NRA seems an unlikely vehicle for strengthening Chartist anti-slavery sentiment, considering

\footnotetext{
${ }^{81}$ Earle, Jacksonian antislavery, pp. 58-61; Lause, Young America, pp. 9-46.

${ }^{82}$ Lause, Young America, pp. 13-19; Wilentz, Chants democratic, pp. 294-362; Claeys, Citizens and saints, p. 245.

${ }^{83}$ Feargus O'Connor, 'The land': the only remedy for national poverty... (Leeds, 1842), pp. 3-5; Practical work on the management of small farms (Manchester, 1847), pp. 8, 31; Northern Star, 23 Apr. 1843; Malcolm Chase, The Chartists: perspectives and legacies (London, 2015), pp. 47-62, and Chartism, pp. 247-70.

${ }^{84}$ Bronstein, Land reform, pp. 23-51; Northern Star, 12 Oct. 1844, 4 Jan. 1845; Working Man's Advocate, 6, 20 Apr. 1844, 8 Feb. 1845; Young America, 28 June 1845; Reynolds' Political Instructor, 30 Mar. 1850.

${ }^{85}$ Northern Star, 21, 28 Nov., 19 Dec. 1846, 2 Jan., 6 Feb. 1847; Black and Black, eds., Harney papers, pp. 61-2.

${ }^{86}$ Black and Black, eds., Harney papers, pp. 67-8; Bronstein, Land reform, pp. 150-6; Northern Star, 1 June 1844, 10 Jan. 1846; Thomas Aigne Devyr, The odd book of the nineteenth century... (New York, NY, 1882), pp. 30-3.
} 
that Devyr, the former co-editor of the apologist Northern Liberator, was now a loyal anti-abolitionist Democrat, while Evans wrote in 1844 to Liberty Party leader Gerritt Smith about how ending 'white slavery' should precede abolition. ${ }^{87}$ As Mark Lause outlines, however, Evans's hyperbole obscures the growing support for anti-slavery within the NRA. In part, this was because the NRA sought to stop the 'slave power' monopolizing western land with large plantations and settle wage labourers there instead, but it was also driven by principle, and Evans and other NRA members sometimes described chattel slavery as worse than wage labour. Although he prioritized white grievances in his letters to Smith, Evans also often emphasized that abolition and land reform should occur simultaneously, with the Northern Star reprinting his arguments that slaves should immediately be freed with smallholdings, a blend of personal liberty with land rights that anticipated Reconstruction-era demands. While this was often framed as a means of stopping freed slaves competing with northern wage labourers, Evans and others also advocated racial equality and the participation of free black workers within the Agrarian movement. ${ }^{88}$ o'Connor similarly referred to the Land Plan as 'a free temple' with 'no distinction of colour', a meaningful statement considering that Cuffay was a manager of the scheme. This attitude of racial equality distinguished the NRA and late Chartism from others within the Free Soil tradition. ${ }^{89}$

In Britain, Chartists were retreating from the absolute notion of 'white slavery' being worse than chattel slavery. Examples of hyperbolic comparisons of wage labour to chattel slavery declined, while the coercive aspects of wages and land dispossession were increasingly dubbed 'wages' or 'operative' slavery. ${ }^{90}$ While Chartists continued to insist chattel slaves benefited from subsistence, they accepted that 'self-ownership' possessed political and psychological benefits. In 1842, the Boston Unitarian W. E. Channing explicitly criticized Chartist use of 'white slavery', pointing out that while 'depressed' Chartism's vibrant intellectual and political culture proved there was no equivalence to chattel slavery. This direct intervention was significant, as Channing was profoundly influential amongst Chartists. ${ }^{91}$ The Abbe de Lamennais's Modern slavery was well-read after being published in translation by the Chartist James Watson in 1840 and influenced understandings of 'wages-slavery' into the late 1850s. Lamennais conceded that 'the proletarian' being 'personally free

\footnotetext{
${ }^{87}$ Devyr, Odd book, pp. 39-40; LeRoy P. Graf and Ralph W. Haskins, eds., The papers of Andrew Johnson, III: 1858-1860 (Knoxville, TN, 1972), p. 311; Northern Star, 20 Apr., 1, 8 June 1844, 18 Apr., 7 Nov. 1846; People's Rights, 24 July 1844; Young America, 26 Apr., 17 May, 21 June 1845; Earle, Jacksonian antislavery, pp. 60-1; Eric Foner, Politics and ideology in the age of the Civil War (Oxford, 1980), pp. 87-9.

${ }^{88}$ Young America, 21 June, 12 July 1845, 2 Feb., 21 Mar. 1846; Northern Star, 9 May 1846; Foner, Politics and ideology, pp. 77, 88; Lause, Young America, pp. 78-83.

${ }^{89}$ Northern Star, 10 July 1847; Foner, Free Soil, pp. 261-300.

${ }^{90}$ For examples of such hyperbole after 1842, see Patrick Brewster, The seven Chartist and military discourses... (Paisley, 1843); National Association Gazette, 19 Mar. 1842; Northern Star, 1 May 1847, 1 Jan. 1848, 15 Dec. 1849.

${ }^{91}$ W. E. Channing, 'The duty of the free states; or, remarks suggested by the case of the Creole', in The works of William Ellery Channing..., VI (Newcastle, 1845), pp. 31-2; Scriven, Popular virtue, p. 107.
} 
by law' allowed the 'moral improvement' that would eventually liberate workers. Nevertheless, wages reduced many workers' conditions 'below that of the slave' since slaveholders possessed 'interest in [slaves'] preservation'. Thus, even though a workers' 'body is not enslaved...his will is'. ${ }^{92}$ Ernest Jones, the poet and late Chartist leader who, after 1850, joined Harney as a leader of Chartism's socialist wing, summarized the difference between chattel slavery and wage labour as that of subsistence without liberty and liberty with starvation. ${ }^{93}$ Despite seeing them as comparable, Harney nevertheless acknowledged that 'personal-slavery and wages-slavery mark broad distinctions between society in America and in Europe'. This comparison was abstract, since although 'free-born Britons' could not be shackled or branded their masters could 'exercise the same power in another form' through conspiracy and starvation. ${ }^{94}$ As a trade unionist, Cuffay had been forced into poverty by just such an employers' conspiracy, and he referred to a meeting of tailors as his 'fellowtradesmen and brother-slaves'. He nevertheless also valued his formal liberty as a wage labourer, often stating that as the descendant of slaves he sought 'the complete emancipation of that nation which had inscribed his name upon the list of freemen'. In any case, Harney was clear that British 'social slavery' should not detract from abolitionism, since 'European wrong forms no justification of American crime...we will not tolerate crimes against liberty because so-called democrats are the criminals. ${ }^{, 95}$

O'Brien had argued in 1835 that property 'is what murders the blacks and Abolitionists of America', but he did not pursue this argument's abolitionist implications, preferring instead Jackson's 'Bank War'. ${ }^{96}$ A decade later, Harney did argue for dual emancipation by renovating O'Brien's and Evans's argument that chattel slavery and 'white slavery' originated in land monopoly. In July 1846, he co-authored an address to the NRA calling for the ending of the slavery of white and black - wages and the whip - by driving from your legislatures landlords, usurers, lawyers, soldiers, and other idlers and swindlers'. Emulating Evans, this address argued that true abolition required personal liberty, a land grant, and the vote simultaneously. ${ }^{97}$ The Northern Star also derived from the NRA the argument that the 'revolution of '76 was only a half revolution', because without a popular movement the revolutionaries of 'the Jefferson stamp' submitted to constitutional compromises that did not touch 'social institutions'. This was the historical root of the 'evil' of 'negro-slavery' and the 'usurpation' that compelled 'the working class to unceasing toil'. Harney's introduction to a collection of abolitionist poetry to mark Independence Day 1847 lamented the partial liberation of the white

\footnotetext{
92 Abbe De Lamennais, Modern slavery (London, 1840), pp. 10-11; Northern Star, 26 Feb. 1848; People's Paper, 29 May 1858.

93 People's Paper, 16 July 1853.

${ }^{94}$ Northern Star, 26 Feb., 23 Sept., 4 Nov. 1848, 11 May 1850, 21 June 1851; Reynolds's Newspaper, 12 May 1850; Newcastle Weekly Chronicle, 15 Nov. 1890.

95 Northern Star, 5 Mar., 11 June 1842, 28 Feb. 1846, 12 June 1847, 11 May 1850; People's Paper, 15 Aug. 1857.

96 Poor Man's Guardian, 15 Nov. 1835.

${ }^{97}$ Northern Star, 11 July 1846; Young America, 11 July 1846; Lause, Young America, p. 76.
} 
man, leaving their black brethren still bound in the fetters of slavery' and hoped for a new revolution. For both Chartists and 'Agrarians', this revolution would preserve American democracy by defeating a monopolizing class depicted as international. As a Young America article reprinted in the Northern Star argued, 'the interests of the landless on both sides of the water are closely connected', their opponents being 'Land Monopolists wherever found', whose control of land allowed a transatlantic depression of wages. For Wheeler, land monopoly had produced 'black and white slavery', but Chartism's 'martyred champions' exiled in America helped found the 'Free Land Movement' that offered 'shelter and protection...to the denizens of the whole world'. ${ }^{98}$ Consequently, the NRA's slogans 'free soil' and 'free labour on a free soil' were widely adopted by Chartists into the 1850s. This left no room for the apologias for southern Democrats seen in the early Chartist era. ${ }^{99}$

Stirrings of this revolution were perceived in the strong NRA and Liberty Party blocs in the 1846 New York State elections. Support for the NRA from Gerrit Smith and others led the Northern Star to argue that a new democratic party was forming from 'the most enlightened' of the Liberty Party, now proven to be 'thorough haters of slavery - white as well as black'. The Northern Star predicted that 'Abolitionists will...unite with the National Reformers' since 'the latter will vote the abolition of black slavery', thereby guaranteeing 'a real freedom to the emancipated-exemption from wages thraldom as well as whip slavery'. Concurrently, Chartists abandoned the Democratic Party following the annexation of slaveholding Texas and the invasion of Mexico. In 1844, the NRA had endorsed the Democrat James Polk for president but found him disappointing. In Britain, Polk had been dubbed the 'Chartist President', but by 1847 the Northern Star denounced him as 'the Louis-Phillipe of the United States' guilty of waging an 'atrocious war of aggression'. Polk's selling of public lands to 'capitalists and SPECULATORS' and 'slave-holders' to fund the unjust war infuriated Young America in an article reprinted in the Northern Star. The Chartist Labourer, edited by Jones, hoped the NRA would crush the 'tendency to despotism' evident in Polk and the conquests of General Zachary Taylor. Links between the war, abolition, and agrarian reform were central to Jones's 'The Age of Peace':

Hark! 'mid Mexico's surrender,

Comes a challenge ill repressed.

Where's thy honour? poor pretender!

Shame! Republic of the West!

Talk no more of freedom's glory,

Manhood's truth and people's right

Thy 'stripes' on slavery's back are gory,

Thy 'stars' shine truly, but in night.

\footnotetext{
${ }^{98}$ Northern Star, 26 Apr., 13 Sept. 1845, 21 Nov. 1846, 23 Jan., 3 July 1847, 15 Sept. 1849; Lause, Young America, p. 50.

99 Young America, 24 May, 5 July, 6 Dec. 1845, 6 Mar. 1847; Northern Star, 19 Sept., 14 Nov. 1846, 22, 29 May, 5 June, 10, 17 July 1847, 1 Jan. 1848, 5, 12, 19 May 1849, 2 Mar. 1850.
} 


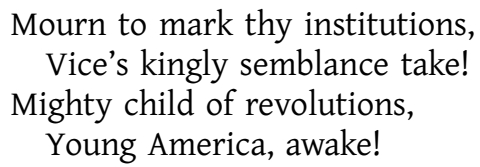

The "progress of the friends of a Landed Democracy-the "National Reformers", claimed the Northern Star on New Year's Day 1848, was 'a pledge for the political and social redemption of the human race'. ${ }^{100}$ This optimism dissipated after the election of Taylor as president at the end of the year, causing Chartists to warn that 'America, with its black and white slavery - the slavery of the whip, and the slavery of wages - is regarded by the European democrats as a Republican sham.' Presciently, Harney noted in 1850 that a 'social revolution in America is a necessary and indispensable complement to the political revolution of ' 76 '. ${ }^{101}$

\section{VI}

By the time of the American Civil War, most ex-Chartists saw eradicating chattel slavery as both a moral end and a means of defending wage labourers globally. In 1862, Harney argued that American slavery, far from being a pre-capitalist artefact of aristocracy, had 'grown and fructified under the patronage of the English manufacturing system'. Further still, he now explicitly thought that chattel slavery was a more severe form of exploitation than wage labour. In the first editorial he sent to President Lincoln, Harney spoke of the 'attempt to establish a new and aggressive Power avowedly based on Black Slavery, and aiming at the enslavement of all Labour whether white or black, for the aggrandisement of an Oligarchy the most selfish, brutal and wicked ever known since the history of mankind'. ${ }^{102}$ In 1863, Ernest Jones was one of the most prominent pro-Union agitators in Britain, similarly warning that America's expansionist slave power saw chattel slavery as the model form of labour across the globe. ${ }^{103}$ Jones had come to this position in the 1850s, when, as Chartism's chief leader in its waning years, he made some of the movement's most strident attacks on American slavery when the prospect of the Republican Party winning the 1856 presidential election seemed real. Jones attacked arguments that chattel slaves were treated better than European workers, that there was no constitutional power to free slaves, and that the south would willingly vote away slavery, all of which had been common early Chartist apologies. Stating that although the Republicans sought 'to give freedom to the black, and slavery to the white' through the extension of

${ }^{100}$ Lause, Young America, pp. 27-8, 77-8; Northern Star, 30 Nov. 1844, 20 June, 26 Dec. 1846, 2, 10, 16, 23, 30 Jan. 1847, 1 Jan. 1848; Labourer, 1 (1847), pp. 89, 240, 243, 284.

${ }^{101}$ Northern Star, 13 Jan. 1849; Democratic Review, June 1849, Aug. 1850; Red Republican, 22 June, 13 July, 14 Sept. 1850; Friend of the People, 26 July 1851.

102 Jersey Independent, 27 Feb., 4 July 1862.

${ }^{103}$ Ernest Jones, The slaveholders' war (Ashton-under-Lyne, 1863). For similar ex-Chartist arguments, see W. E. Adams, The slaveholders' war: an argument for the north and the negro (London, 1863); G. J. Holyoake, The liberal situation (London, 1865), p. 48. 
wage labour, he nevertheless declared that 'we should certainly vote in favour of the anti-black-slavery candidate'. Predicting a civil war, Jones hoped that the north 'will conquer the dissolute and despotic south', ending 'slavery at any cost - perish slavery in every form and clime'. ${ }^{104}$

The weight of scholarship on this period suggests that working-class radicals in Britain, including ex-Chartists, were mostly pro-Union during the Civil War. This article has outlined how this shifted from the resentful anti-abolitionism of the early Chartist period, with the mid-1840s a key turning point. ${ }^{105}$ By appropriating the Free Soil tradition, Chartist intellectuals like Harney and Jones were able to combine a moral abolitionism informed by Garrisonianism with an opposition to slavery as a form of land monopoly detrimental to American and British workers. In this form, anti-slavery sentiment survived its increasing divorce from mass politics elsewhere in British society. ${ }^{106}$ By 1863 , the Republican Party was a vehicle of both emancipation and, through the Homestead Act, modest land reform, and former Chartists were subsequently integral figures in the drawing up of addresses sent by workers' meetings and associations from Britain to Lincoln, celebrating 'liberty of free labor upon a free soil', a convergence of Republican policies with the recent thought of British radicalism. ${ }^{107}$ This close entwining of agrarianism with anti-slavery in Chartist thought helps explain why common ground could be found between workers and former free trade antagonists, such as John Bright, not only pro-Union but increasingly taking land and social reform seriously. ${ }^{108}$

While British society had become more racist, as Frederick Douglass noted during his second visit in 1859, the bulk of the British labour movement had become less so since 1838-40. ${ }^{109}$ This should not be overstated. Ethno-cultural ideas of race growing in other areas of British society evidently influenced Jones, while his collaborator Karl Marx believed that black Americans were culturally and intellectually superior to other black populations. In 1853, Harney took seriously a letter from the ex-Chartist New Yorker Charles Keen suggesting that, unlike British black people, racial prejudice had degraded the free black population beyond political competency. Chartist freethought culture still saw racial difference as a topic of discussion, even if racist caricature and slavery apologia were now considered vulgar. ${ }^{110}$

\footnotetext{
${ }^{104}$ People's Paper, 12, 26 July, 6 Sept., 22 Nov. 1856.

${ }^{105}$ R. J. M. Blackett, Divided hearts: Britain and the American Civil War (Baton Rouge, LA, 2001); David Campbell, English public opinion and the American Civil War (Cambridge, 2003); Philip Foner, British labor and the American Civil War (New York, NY, 1981); Royden Harrison, Before the socialists: studies in labour and politics, 1861-1881 (Toronto, ON, 1965); Eugenio Biagini, Liberty, retrenchment and reform: popular liberalism in the age of Gladstone, 1860-1880 (Cambridge, 1991).

${ }^{106}$ Drescher, Abolition, pp. 277-9; Huzzey, Freedom burning, pp. 5-20, 75-97.

${ }^{107}$ Foner, Free Soil, pp. 27-9; R. Moore to Abraham Lincoln, 31 Dec. 1862, Abraham Lincoln papers, Library of Congress; Bee-Hive, 17 Sept. 1864, 7 Jan. 1865.

${ }^{108}$ Margot Finn, After Chartism: class and nation in English radical politics, 1848-1874 (Cambridge, 1993), p. 263; Biagini, Liberty, pp. 69-83.

109 Blackett, Divided hearts, pp. 36-47.

${ }^{110}$ Notes to the people, II (London, 1852), p. 667; People's Paper, 26 July 1856; Andrew Zimmerman, ed., The Civil War in the United States (New York, NY, 2016), pp. 10-11; The Vanguard (London, 1853),
} 
More consistently, however, Jones sided with colonial resistance, with his People's Paper seeking to educate 'Europeans and Americans who may be disposed to look down on negro races'. The ex-Chartists W. E. Adams, Joseph Cowen, and G. J. Holyoake were notable amongst those who supported the refugee slave William Craft's celebrated refutation in 1863 of Dr James Hunt's biological racism. ${ }^{111}$ Transatlantic black radicalism, but also the NRA, had confronted Chartists with the humanity of black people and a perception of a shared status as oppressed and exploited labourers. Wartime arguments that slaves would prove fit if immediately granted equal political and civil rights originated within late Chartism, and it is noteworthy that most identifiable ex-Chartists in America in the 1860s were active Radical Republicans. One of these, Harney, was also American correspondent for Cowen's Newcastle Chronicle, where his advocacy of equal rights for black Americans was rooted in the positions he had developed as a Chartist leader and intellectual. ${ }^{112}$ As Harney said of a lecture he attended by Wendell Phillips, his 'arguments in favour of admitting the Negro to equality of franchise with the white man were identical in spirit and substance with our old Chartist pleas'. ${ }^{113}$

This is illustrative of the varied long-term Chartist legacy beyond the narrow terms of whether the points of the Charter continued to be pressed by labour radicals in Britain after the movement's dissolution. It is evident that broader definitions of political and social rights that originated within Chartism continued to be maintained well into the 1860 s by both ex-Chartists and their younger successors within the British labour movement. Born in the 1840s of the transatlantic influences of abolition, black radicalism, and land reform, this British 'Free Soil' tradition eclipsed the anti-abolitionist and virulently anti-black hyperbole of early Chartism with an expansive definition of democracy that asserted rights to the land and capital not only for all wage labourers but also chattel slaves, and with that the granting of political rights irrespective of race. ${ }^{114}$

Acknowledgements. I would like to thank the editorial team and anonymous reviewers at the Historical Journal for their work and advice on this article. I would also like to thank Dr Jessica Patterson for providing her thoughts on this research.

p. 40; Peter Mandler, “Race" and "nation" in mid-Victorian thought', in Stefan Collini et al., eds., History, religion, and culture: British intellectual history, 1750-1950 (Cambridge, 2000), pp. 224-44.

${ }^{111}$ Blackett, Divided hearts, p. 42; People's Paper, 17 Oct. 1857.

${ }^{112}$ Newcastle Chronicle, 7 Jan., 13 May, 5 Aug. 1865, 6 Jan. 1866, 30 Mar. 1867.

${ }_{113}$ Bee-Hive, 6, 20 May 1865; Newcastle Chronicle, 9 Dec. 1865; Josh Gibson, 'The political thought of the Chartist movement' (Ph.D. thesis, Cambridge, 2017), pp. 221-33, 239-44.

${ }^{114}$ For a discussion of such a Chartist definition of democracy, see Peter Gurney, 'The democratic idiom: languages of democracy in the Chartist movement', Journal of Modern History, 86 (2014), pp. 566-602.

Cite this article: Scriven T (2022). Slavery and Abolition in Chartist Thought and Culture, 18381850. The Historical Journal 65, 1262-1284. https://doi.org/10.1017/S0018246X21000819 